\title{
Local Wisdom of Malay "Tradisi Turun Sungai" in preventing Flood at East Coast of North Sumatera
}

\author{
Wan Syaifuddin 1 , Roma Ayuni A. Loebis ${ }^{2}$ \\ \{1 syaifuddin@usu.ac.id., ${ }^{2}$ roma@usu.ac.id\} \\ ${ }^{1}$ Malay Studies Program, Faculty of Culture Science, University of Sumatera Utara \\ ${ }^{2}$ English Literature Department, Faculty of Cultural Science, University of Sumatera Utara
}

\begin{abstract}
Tradisi Turun Sungai (Down to the river) is a local wisdom of Malay society of East Coast of North Sumatera (PTSU). The performance shows petuah and meaningful proverbs which influence the society attitude to prevent flood. This article discusses and analyzes the east coast area of North Sumatera which flood occurred annually due to the lack of awareness of the society in understanding their mutual relationship with the river physically. The flood disaster is overcome by through local wisdom Tradisi Turun Sungai by rising the society awareness and passion toward the existace of river in the their lives. This analysis uses Descriptive qualitative method with the cultural and functional approaches toward local wisdom. The local wisdoms should be packed up in performances in order to get the image of the river's wisdom and to be tighten up with the society's behavior. The result shows that through the awareness and caring toward the river and also the local wisdom play a great role in preventing flood
\end{abstract}

Key words: Local wisdom, Tradisi Turun Sungai and flood prevention

\section{Introduction}

On certain time, flood often occur in the area of east coast of North Sumatera. This annualy disaster happens not without any reason. Many factors cause flood, such as uncovered forest especially at the upper reaches and waste pollution from houses and industries. In the documentation of [1] and Sumatera Office of River Territories (BWSS) also Organization Office of River Bank Area (BPDAS) in Medan, North Sumatera flood occurs annually in rainy season. This due to the behavioral pattern of the people who live along the river area who cut down trees improperly (Hydrology Ecology) and at the lower reaches is found improper structure and arrangement in organizing houses and buildings, sanitary and drainage (Hydrology Technology). Referring to [2] shows that lack of awareness of the society who live in the river area in maintaining their mutual relationship with the river, both physically and mentally.

According to [3] states that custom, adat, language and religion is the basic value system in the life of society in East coast North Sumatera (PTSU), especially who hold adat, culture, utter Malay language and believe in Islam. This rank of value systems bulid the mindset and behavior of its society who realize that treating nature as spiritual reality; language is the 
symbol of good character, language shows inner side; and brotherhood should exist in togetherness (treating the nature as the spiritual reality; Language is the symbol of good manner, language has to shows the inner spirit; and brotherhood should exist in togetherness). Meaning that the society in east coast in North Sumatera build good character in their daily lives and be orientated that not only plant shows the living element, but ground (land), water, (river and sea), sky, sun, and moon also radiate the same elemets from the same lives.

In accordance to the value system basically society of East coast North Sumatera refer to the watery area (river and sea). For that matter, the society especially Malay society in some social studies often called as Aquatic society [4][5][6] . River and sea have been considered as place orientation because river and sea provide various functions; communication, transportation, make a living, market system, amusement, tourism, more over a cultural-cross and gate to interact with another wide world. On certain time, as a navigation to determine hisab on ramadhan and praying time in Islam.

Some wide rivers which flow in East coast of North Sumatera are Tanjung Pura, Wampu, Deli, Denai, Belumai, Ular, Asahan, Billah, and Barumun rivers. All boil down to Malaka strait. Those rivers, basically the upper reaches and lower reaches are low and high lands which link the swamp, down hill.

Referring to [7] shows that in one side the river continent for the society of East coast of North Sumatera is the material and creative concept in practicing adat being cultured, and the manifestation of taqwa (strong believed) and also harmony, which become the imajery of local wisdoms of its society. On the other side, when referring the sea existence's point of view and events in the environments, the value and the meaning of local wisdom become the responsibility holder for the society not to pollute and damage the river so the society will keep the environment clean and will make effort to prevent flood.

As [8] also states that local wisdom is various of wisdom which inherent for long times and fuction to help the social and cultural relationship of its society. The factor which makes the local wisdom become strategic because; Local wisdom is identity builder which inherent since birth; Local wisdom is not something unknown for its owner. As the same opinion as [9] states that local wisdom is from local capability which from various forms of plasma nutfah, in ecology space. Principally, local wisdom as guidance, value management and life surveyor and enviromen surveyor. For example, petuah and proverbs as local wisdom become inspiration to form communal laws which produce local wisdom in giving meaning to the principle and philosophy of life.

Looking at the flood disaster, the value system and place orientation also the result of research on local wisdom of east coast society, it can be described how the existed local wisdom be developed and maintained through performance or shows in Tradisi Turun Sungai which meaningful to the east cost society in preventing flood. Some previous reseach on various place have been done such by [10]Yuniarti (2018) in Rontu river at Bima city and [11]Naping at Barru district in South Sulawesi (2019)

\section{Research Method}

This research used Desriptive qualitative method with cultural and functional approaches toward the local wisdom. The data reduction [12] refers to the process of selecting, focusing, simplifying, abstracting, and transforming various local wisdoms as the way of life of the society in behaving, performing and acting in daily lives for the awareness and passion toward 
the river. The data appeared in written field notes or transcription. The researcher selected and categorized the data based the function of petua and expressions as the adaption in facing the nature of the river and taking care the river not to be damaged or tained through the performance and shows which has meaning i). river as the facility of amusement/ tourism object; ii) river as the media of taqwa and iii). river as media in building harmony among society in east coast of North Sumatera as the way of life in preventing flood.

\section{Results And Discussion}

\subsection{River an agility arena and amusement arena/tourism}

Various activities that use river as the arena of agility and amusement or tourism object in which the existence is inherent. Some of local wisdoms are called Tradisi Turun Sungai, Tradisi Pacu Jalur, and Lomba Pacu Sampan also Lomba Sampan Tradisi juga Festival Air. Each tradition is collective activities for society member who live in east coast of North Sumatera. This collective activities often held in public days such on Indonesia Independence Day, Anniversary of Region Government or Anniversary of the city, National Education Day, also Hari Keputeraan Sultan/Raja (Birthday anniversary of Sulthan or King) and held by the rivers along east coast of North Sumatera. Unfortunatelly, these activities are not held so often nowadays. Only certain communities still hold the ceremony.

In holding Tradisi Turun Sungai and Pacu Jalur also Pacu Sampan all the rules and instruction to theparticipants are collected in petuah and expressions which has purpose that all participants are in order in joining the competition and on the other side to make all participants understand the meaning of the competition and the relationship between the occasion and behavior in keeping the river clean. The expression as follow;

"Membelakangi syarak", meaning of this expression in rule that the participants should obey norms dan religious value. For example, cheating in the competition and using "jampijampi". If the rules are denied, participants or member of the groups will bring inharmony among society members towards the cleaness and the river environment. Moreover, not forgetting the meaning of expression "Membuang Adat Lembaga". The meaning of this expression is that participants should not underestimate or humiliate and saying bad things or neglecting adat and institution which honored by the society and neglecting the cleaness of the river and the environment and creatures (fish and grass) in the river. Hence, participants should understand the meaning of petuah "Bermanja-manja". The wisdom of this petuah shows that participants should not be spoiled. If happens, participants willn not be independent and not able to face problem by themselves. Always want to rely on others help and depend on others, also act childish. So they can not stand alone or depend on themselves in facing natural events in the river such as pusaran (whirl) and lubuk (hole) in the river.

Petuah "Bercawat ekor" is one of the petuah that made as the rule to the participant. Meaning that participants should not be coward and scare which make them under pressure and have no spirit. If participant are coward, than they will not be harmony with the river. "Menjilat ludah"; is also petuah that should be conveyed to the participants as the guidance in competition. Meaning of this petuah shows that participants should not cancel what he has uttered earlier. Denying what he had said before and having no responsibility to what he had said and decided. If this haapens, a person or society will be weak and has no identity in the river. Meaning that participants "Membuang petuah"; because this wisdom clearly shows that 
participants should listen to advice, petuah, and other mandate. Paying attention to others suggestion and opinion. If not doing so, meaning he reject tuah (luck) of victory on himself when competing in the river.

Other petuah also delivered to participants in joining the competition in the river in tradition Turun Sungai truthfully shows how to build awareness upon good mentality toward the river, especially to the cleaness and river environment also the empowerment among the society member at east coast of North Sumatera. Other petuah and expression are; tuah "Jangan Membabi buta". The wisdom meaning of this petuah in competition shows that participant should not be too emotional dan should not do something which is not based on normal and mature thinking. Participant should not act reckless and speculate when in the river. The same petuah as petuah "Berburuk sangka", the wisdom of this expression shows in competition, participants should not have prejudice to others and shows jealousy, envy, and not believe in others and always suspicious of other people.

Truthfully, aside petuah and expression as the rule or regulation for participants in competition above, there are more other petuah and expressions. There are even more petuah and expressions live and develop in another river area. But, those which have been mentioned above revealed only to support those petuah and expression as the form of harmony of the people to tighten the bond among the society member and as the reflection of harmony of the society member to build dignity for people who live along the river side in east coast of Sumatera.

\subsection{River as the means of Taqwa}

The culture of the society who live along the river has sublime values inside their local wisdom. The society members state that since hundred years ago the values and the meaning have become their identity.These wisdom values are believed able to raise their harkat (dignity) and marwah (good name) in a large meaning. Anyone will use this as his character and identity which will make him as person with tuah, dignity as the relection of taqwa (strong beliefs) and also has awareness of how important to maintain the clean environment of the river.Values from the local wisdom in the river will build one of the expression: "Sifat tahu asal mula jadi, tahu berpegang pada yang satu", meaning that the wisdom of the society toward river by realizing that he is a human who are created by Allah SWT. This awareness leads to taqwa, obeying all God's rule in life and keeping away from all the bans, and try to make himself a good person so he will granted by Allah SWT to be given mercy in this world and the day after. With this awareness he will try to upgrading his beliefs his qualities in Islam, and make himself as a worthy person for all mankind and be responsible in keeping the nature including taking care of the river and other creatures.

A slight different with the meaning of petuah "Sifat tahan menentang matahari". The wisdom of its meaning shows that the society members who live along the river should be brave, and never give up, be patient in facing problem, be independent in life and keep trying, should not scare in facing challenge and be tough in facing enemy, also willing to die and sacrifice for his religion, nation and country. He also has to be responsible for keeping his environment. This wisdom shows that society who live along the river are persevering to face challenge in life. They are independent, diligent and hard working in getting their rights and doing their obligation. Tough in maintaining the beauty and the sustainability of the river.

All the meaning of petuah and expression which live among the society who live along the river on east coat of North Sumatera forbids the character and the act which not good and overreact to exploite the river. It includes various character such noble and wise which 
commonly regarded as "Sifat tua", or "Sifat Jati". Also can be said as : "apabila hendak menjadi orang, sifat yang pucuk harus di pegang", or said as: "Apabila hendak jadi manusia, sifat yang pucuk jadi pakaian "or said as :"Tanda manusia sempurna ahlak, sifat yang pucuk tempatnya tegak" or said as "tanda orang sempurna budi, sifat yang pucuk ia hayati", or said as :"Apa tanda orang terbilang, sifat yang pucuk ia pegang “.

\subsection{River builds Harmony}

Petuah and expression as the local wisdom at the society along the river on east coast of North Sumatera says that :"hidup sebanjar ajar mengajar; hidup sedusun tutun menuntun; hidup sekampung tolong menolong; hidup senegeri beri memberi; hidup sebangsa rasa merasa", which has meaning to reflect values of respect on other people, values of unity and be united, values of team-work, values of hand-in-hand together, values of toleration, values of togetherness in society, in nation and in a country.

Another petuah which says: "adat hidup berbilang suku, jauhkan sifat seteru berseteru; adat hidup berbilang bangsa, jauhkan sifat berburuk sangka". The meaning is to express honored behavior, to keep away from character that can cause conflict, disengagement among the society members because using the river unproperly. Hence, petuah which remids of :"adat hidup di sungai, arif menyimak pantang dan larang; adat hidup di sungai arif menjaga marwah diri", having wise character and knowing how to live along the river as the home town. (Tengku Muzuar, 67 and Dt. Filiyansyah, 61-interviewed at Dt. Filiyansyah's house 23 July 2019)

Basic petuah and expression above should be observed because it worthy as the basic and reference in daily life especially along the river to gain secure, orderly and harmony in the environment. Eventhough the society member in East coast of North Sumatera are from various etnic groups and various nations, those local wisdoms able to gather them to live based on adat and culture. The local wisdom which based on adat and culture values at the river formed in petuah and expressions, able to realize orderly, secure, peaceful and harmony in life. And of course, also realize the cleanliness on the environment of the river. Able to conquer the challenges of disaster which caused by the river and able to suit theirselves properly in life of society, nation and as one country.

Basic values which mentioned above are just some of the various values which existed in the local wisdom of society who live in east coast of North Sumatera. Those values can be used in order to maintain orderly, secure and peaceful lives also being in harmony. This holy petuah can be as the adhesive in living as society, nation and country. At least it can be the adhesive for group of society members in living together along the river and to keep the river cleas as day by day the river is getting crushed by many aspect. These wisdom character owned by people who live along the river are used as the identity and should be used in daily life. Truthfully, in every local wisdom the interpretation of the meaning can be expanded so it ca be used widely. Therefore, in every ceremony of adat, these petuah and expression is uttered and delivered by old people so everyone can hear and understand the meaning of each petuah and appreciated the petua from the bottom of their heart. This tradition which bequeath for the society shows the people have a great consideration to the safety of their people from flood disaster caused by the river

From the previous analysis [13] has stated that there are various values and norms of local wisdom of people at east coast of Sumatera which function to maintain the social life to gain harmony, taqwa, and harmonious life with the river by keep the cleanliness and the environment to avoid flood. 
Understanding and analyzing and discussing those local wisdom concerning the benefit to overcome flood. At least those local wisdom can be the effort to avoid flood. Those local wisdom at can be formed in amusement activities or tourism object and also the facilities to build stong belief in God (taqwa). River is used as the the facility to build harmony among society members by having performance and attraction near the river as the reminder. The occasion should be scheduled, at least on celebration day. The performance of Turun Sungai as local wisdom can be formed wider so it can be the arena in performing the values and norms of the local wisdom.of its society.

Technically, on the day it is announced that Tradisi Turun Sungai with all the activities such as festival or competition, it is also served the values and meanings of each local wisdom at the sea of the society in east coast of North Sumatera as the part of the performance. Meaning that Tradisi Turun Sungai is not just only serving the norms and values in Tradisi Turun Sungai but also can be formed in society's activitiy and reveal another local wisdom such as wisdom which related to build taqwa and harmony among society member through local wisdom at the river. Truthfully, the form of Tradisi Turun Sungai is for the sake of maintaining the existence of the values and norms also the meaning to bulid mentality of the society members at east coast of North Sumatera toward river, moreover to solve the flood problem in life which often occur due lack of awareness toward wisdom of the river.

On the day of Tradisi Turun Sungai the present of all society members is a must. It is because the occasion is filled by cultural tradition activities of society members at east coast of North Sumatera. Those cultural tradition activities, such as Lomba Sampan Tradisi (Traditional boat competition), Festival Laga Bongak (Sungai Billah), Festival Sampan Hias, dan Sayembara Dondang Syair Sungai (sungai Asahan) serta Bersyair Dondang Padang Rebah (sungai Padang). The time of the occasions depends on the purpose on celebrating specific events. And the theme also adjusted on current issues and phenomenon on river. But the theme and the time still show and related to the character of adat dan culture of the society. Therefore the day of the occasion usually only for two days (Saturday and Sunday). But the preparation and the occasion may take longer time. If possible the preparation can take one month because will be used to socialize the values and norms and the meaning of each local wisdom concerning in preventin flood.

Moreover, the facilities that are used in every festival and competition in Tradisi Turun Sungai should be formed in conveying values and norms also meaning of those local wisdom about the river and the honour in preventing flood. And the form of the facilities should be adjusted with the awareness to the cleanliness of the river and the environment. There should be a pocket book which accompanied the Tradisi Turun Sungai festival which is contain the regulation that should be obeyed by the participants and added with values, norms and meaning of each local wisdom. Printed attractively to make the society and the reader eager to read, understand, and enjoy the book. When the reader comprehend the meaning, the values and the norms will attached on their mind and effect their way of thinking. Finally it will give good impact to their behavior and awareness toward their environment and the river. Along with that, the condition of festivity on the occasion of Tradisi Turun Sungai which planned with all promotion of the activities through social media, electronic media, poster and billboard [14]. 


\section{Conclusion}

Understanding and comprehending, and appreciating the local wisdom toward the river on society member at east coast of North Sumatera enable the society to keep the cleanliness of the environment and the river area to prevent flood are formed and existed in their lives. Local wisdom is not only the value which has benefit in the culture itself, but local wisdom can be used to solve problems in life nowadays and the future. Empowerment of the local wisdom toward the river for the society members at east coast of North Sumatera is the formed in the performance of Tradisi Turun Sungai with all the activities to maintain the cleanliness and the river area as the imagery to local wisdom and the society members so it is attached to their behavior. Eventually, the awareness and the passion of society members at east coast of North Sumatera to keep the river area clean will gradually erase the unproper acts toward the river and the environment. Finally, it will bring the balace in life between people/ society members at east coast of North Sumatera and the river, that day will be free from flood.

\section{Acknowledgement}

This research was supported by University of Sumatera Utara under contract of Research Implementation Talenta USU, number: 4167/UN5.1.R/PPM/2019 dated 01 April 2019

\section{References}

[1] BNPB, "Profil Kebencanaan."

[2] W. Syaifuddin, "Malay Oral Literature on Billah Riverside and Flood Prevention," vol. 231, no. Amca, pp. 32-35, 2018.

[3] U. Hamidy, Kearifan Orang Meayu Memelihara Lingkungan Hidup. Pekan Baru: UIR Press, 2005.

[4] E. Revida, Pemikiran Guru Besar Universitas Sumatera Utara. Medan: USU Press, 2019.

[5] L. W. Morton and K. R. Olson, "The Pulses of the Mekong River Basin: Rivers and the Livelihoods of Farmers and Fishers," J. Environ. Prot. (Irvine,. Calif)., vol. 09, no. 04, pp. 431459, 2018.

[6] M. Ribka, "Water Security in the Mekong River and Regional Stability in Southeast Asia," vol. 2, no. 1 , pp. $26-36$.

[7] Subhilhar, Pemikiran Guru Besar Universitas Sumatera Utara "Pendidikan Tinggi di Era Revolusi Industri 4.0.” Meda: USU Press, 2012.

[8] W. Syaifuddin, Pemikuran Kreatif dan Sastra Melayu Tradisi. Yogyakarta: Gading, 2016.

[9] Y. Yusuf, "Hutan, Tanah dan Penyusutan Kebudayaan (Tari Menarik Melayu Riau dalam keIndonesiaan)," Lingua, vol. 2, 2010.

[10] R. K. Yuniarti, "Mitigasi Banjir Struktural dan Non-Struktural untuk daerah Aliran Sungai Rontu di Kota Bima," Penelit. Pengelolaan Drh. Aliran Sungai, vol. 2, no. 2, 2018.

[11] H. Naping, "A Strategy of Local Wisdom based Natural Disaster management in Coastal Communities in Barru District, South Sulawesi," IOP Conf. Ser. earth Environ. Sci., vol. 235, 2019.

[12] M. B. and A. M. H. Miles, Qualitative data Analysis: A Method Source Book. London, United Kingdom: SAGE Publication, 2014.

[13] W. Syaifuddin, "Pemberdayaan Nilai-nilai Kearifan Lokal (Sastra Lisan) Melayu terhadap Pemeliharaan Daerah Aliran Sungai (DAS) pada Masyarakat Sumatera Utara (Studi Kasus Sungai Wampu, Deli, Ular, Padang, Asahan dan Sungai Bilah),” 2017. 
[14] B.W. Setyawan and K. Saddhono, "Eret traditional ceremony as representation of spirit of mutual cooperation among coastal communities". Adv. Sci. Let. vol. 23 no.10, pp 9991-9992, 2017 